\title{
Green Finance and Sustainable Development Goals: The Case of China
}

\author{
Jung Wan LEE ${ }^{1}$
}

Received: February 25, 2020 Revised: May 31, 2020 Accepted: June 10, 2020

\begin{abstract}
The paper seeks to explore the role of green finance in achieving sustainable development goals through the case of China, and address some issues of sustainable finance and environmental, social and governance concerns of green finance by introducing the episodes of green finance in China. This paper aims to provide some viewpoints about the following questions: 1) What are the latest trends in green finance? 2) What are the main challenges to the development of green finance? 3) What are policy recommendations for the development of green finance? 4) What are the roles of both the public and private sectors in promoting green finance? This paper identifies the mainstream to sustainable bonds, diversification of green finance, transition of corporates' business models, transparency and disclosure, and harmonizing taxonomy and measurement of green finance for the emerging trends of green finance. As the results, this paper recommends some policy measures for the private sector such as greening the banking system, greening the bond market, and greening institutional investors. This paper also suggests some policy initiatives for the public sector such as developing policies and capacity, promoting market transparency and governance, and promoting private-public partnership for diversifying resources of green finance.
\end{abstract}

Keywords : Green Finance, Sustainable Finance, Sustainable Development. Sustainable Development Goals, China

JEL Classification Code: E65, F18, F64, G18, G28

\section{Introduction}

According to the United Nations Environment Programme (UNEP), green financing is to increase the level of financial flows (from banking, micro-credit, insurance and investment) from the public, private and not-for-profit sectors to sustainable development priorities. A key part is to better manage environmental and social risks, take up opportunities that bring both a decent rate of return and environmental benefits and deliver greater accountability. In simple terms, green finance involves engaging traditional capital markets in creating and distributing a range of financial products and services that deliver both investable returns and environmentallypositive outcomes. This involves internalizing environmental

${ }^{1}$ First Author and Corresponding Author. School of International Economics and Trade, Anhui University of Finance and Economics (AUFE), China [Postal Address: 962 Caoshan Road, Bengbu City, Anhui Province, China 233030] Email: jungwan.lee@aufe.edu.cn

(c) Copyright: The Author(s)

This is an Open Access article distributed under the terms of the Creative Commons Attribution Non-Commercial License (http://Creativecommons.org/licenses/by-nc/4.0/) which permits unrestricted noncommercial use, distribution, and reproduction in any medium, provided the original work is properly cited. externalities and adjusting risk perceptions in order to boost environmentally-friendly investments and reduce environmentally-harmful ones. Promoting green finance on a large and economically-viable scale helps ensure that green investments are prioritized over business-as-usual investments that perpetuate unsustainable growth patterns.

The focus can be on the greening of existing infrastructure spending or mobilizing additional investments in key sectors, such as clean energy, sustainable transport, natural resources management, ecosystem services, biodiversity, sustainable tourism, and pollution prevention and control. To satisfy the growing demand, new financial instruments, such as green bonds and carbon market instruments, are being established, along with new financial institutions, such as green banks and green funds. Together, these instruments and institutions constitute green finance. Green financing could be promoted through changes in countries' regulatory frameworks, harmonizing public financial incentives, increases in green financing from different sectors, alignment of public sector financing decision-making with the environmental dimension of the Sustainable Development Goals (SDGs), increased investment in clean and green technologies, financing for 
sustainable natural resource-based green economies and climate green economy, increase use of green bonds, and so on.

UNEP has been working with countries, financial regulators and the finance sector to align financial systems to the 2030 sustainable development agenda - to direct financial flows to support the delivery of the SDGs. At the core of today's globalized economy are financial markets through which banks and investors allocate capital to green business sectors. The capital allocated today shapes ecosystems and the production and consumption patterns of tomorrow.

UNEP, through its resource efficiency program, offers countries the service of reviewing their policy and regulatory environment for the financing system, developing sustainable finance roadmaps, and assisting central banks and regulators on how to best improve the regulatory framework of domestic financial markets to shape the way and supporting multi-country policy initiatives at sub-regional, regional and global level (United Nations Environment Programme, 2020). UNEP also catalyzes the policy action that inspires and informs both public and private investors.

This paper aims to provide some viewpoints about the following questions: 1) What are the latest trends in green finance? 2) What role could the green finance play in sustainable development? 3) What are the main challenges to the development of green finance? 4) What challenges would be met while promoting green finance in China? 5) What are policy recommendations to the development of green finance in China? 6) What are the roles of both the public and private sectors in promoting green finance?

\section{Recent Trends in Green Finance}

In 2019, investors globally continue to be concerned about climate change risks and the transition to a low-carbon economy. The growth in the green finance market for issuers has been especially strong since the introduction of green bonds. With green bonds picking up pace, both government and business entities have started to explore opportunities, and diversify their bond portfolios by incorporating social and sustainability factors. With this backdrop, we summarize recent trends of green finance as follows.

\subsection{From Green Bonds to Sustainable Bonds}

According to a report by Sustainalytics (2019), investors are increasingly using the SDGs as a benchmark for impact and are creating more demand for sustainability bonds. Companies struggling to find assets to benchmark the size of a green bond, have started to look beyond green assets to match treasury needs. They are looking to social assets (i.e., assets with a positive social impact), particularly in new markets like Asia where greater flexibility in choosing assets, allows for faster growth. In particular, there was a match made in heaven between the Chinese leaders announcing more investments in sustainable projects and the demand for Chinese green bonds, coming largely from European investors. The explosion of the market in the past years has been continued in 2018 and the years to come.

In an overall perspective, global green bond issuance reached record highs in 2019. With the equivalent of USD121 billion green bond issuance, it outperformed the previous record from 2018 of USD103 billion. Corporates alone stand for USD50 billion, which is more than a $100 \%$ increase from 2018 (Rooney, 2019). The EUR market alone stood for more than half of the volume (Sustainalytics, 2019). This push and pull effect means 2019 has seen an increase in sustainability bond issuances. The bond market may also have seen the appearance of other labels already proliferating in the loan market, such as environmental, social, and governance (ESG) performance incentive loans. The focus on SDG finance has been increased in 2019, with growing volumes of sustainability bonds. This trend will probably affect the issuance of green bonds, although they will remain the main tool to develop sustainable finance. The market will further diversify into other labelled bonds, allowing investors to make more bespoke choices.

\subsection{Diversification of Green Finance}

According to the European Commission (2018a), at the beginning of 2017, only $17 \%$ of Europe's sustainable investment funds were categorized with an environmental focus. By the end of 2018, this number has increased to $23 \%$, accompanying increased allocations to investments dedicated to fighting climate change. Banks and financial institutions have yet to reach the full potential of their role in developing sustainable finance. The hint given by the European Commission's Vice-President Valdis Dombrovski in December 2018 that the Commission is considering the creation of a "green supporting factor" is set (European Commission, 2018a; Financial Times, 2018). With the promise of a green supporting factor, which would reduce the capital charges levied on banks for their green investments, comes a clear route to expansion of new sustainable investment products.

Insurance companies and pension funds are considerably exposed to the long-term risks of climate change. They are also ideally positioned to invest in sustainable solutions, due to their longer-term investment horizons and massive capital pools. For example, the Commission has seen most of the top European insurers committing to divest from coal, pulling out USD20 billion of investments (Financial Times, 2018; European Commission, 2018a). Regulation and longterm climate change risks have been pushing pension funds to take action, too. The revised EU Directive on Institutions for Occupational Retirement Provision (IORPs), known as 
IORP II, entered into force in January 2017 and member states have until 2019 to implement it. Requirements include consideration of ESG factors in relation to investments, and a scheme's statement of investment principles outlining how investment policy considers ESG factors. With growing scrutiny on corporate actions, banks, asset managers and investors must be clear on their values and the actions they are taking to authentically embody their values. This mission will lead a more diverse offer of green funds, which creating dedicated 'purely green' funds to match this demand.

\subsection{Transition of Companies' Business Models}

With regulatory and policy pressure from the Paris Agreement, OECD, the European Commission's Technical Group on Sustainable Finance, and other national bodies, investors are asking companies to embrace the transition to a low-carbon economy (Sustainalytics, 2019). Investors are looking for companies to demonstrate how a green bond contributes to their transition strategy, and other sustainability commitments. Investors also want to see a change in business models, as companies embrace the transition to a green economy. Every technology eventually become obsolete or replaced by a better, more sustainable version. The same holds true for coal power generation or fossil fuel vehicles, so investors pay attention to how organizations align their business strategies with the policy pathways drawn by the Paris Agreement and regional or national commitments.

The financial services sector is finally taking ESG seriously and not looking back. Increasing awareness of ESG issues, combined with the finance sector's growing understanding of the impact ofESG on corporate performance, is driving banks, asset managers and investors to integrate sustainability data into decision making at unprecedented levels (Sustainalytics, 2019). ESG data has matured to the point where it has been embraced by the finance sector as a key way to identify the companies positioned to succeed, and those that may underperform or fail.

\subsection{Transparency and Disclosure}

Issuer's sustainability strategies become increasingly important for investors, in addition to project-level impact from green bonds. Investors started to ask for increased disclosure around companies' ESG ratings to better understand the company's exposure to climate risk. Investors will look to use indicators showing the impact achieved by green bond financing to make investment decisions. Although impact figures between issuers will remain difficult to compare, the increasing market practice of publishing methodological notes will make comparability easier (Sustainalytics, 2019; United Nations Environment Programme, 2018).
Leading banks and investors are increasingly integrating climate risk in their operations and are transitioning from measurement to management. Banks and investors are increasingly collaborating to develop metrics, engage with companies and demand greater government action on climate. For example, UNEP Finance Initiative and 16 of the world's leading banks came together to pilot implementation of recommendations by the Taskforce on Climate Related Disclosures (TCFD) and develop scenarios, models and metrics to enable assessment and disclosure of climaterelated risks and opportunities (Sustainalytics, 2019).

Following the publication of the TCFD guidelines and the relating first status report, organizations are increasingly aware of the risk environmental issues pose to their business (Climate Disclosure Standards Board, 2018). More players will make decisions based on the environmental, social or governance risks they think an organization is exposed to. The issuers' profiles are likely to become just as important as the projects financed through their green, social and sustainable bonds. Investors will not shift their focus overnight, but their demands for increased transparency will mark this transition period.

\subsection{Taxonomy and Measurement of Green Finance}

The final report of the EU Commission's Technical Expert Group on establishing an EU sustainability taxonomy has been released on March 2020 (European Commission, 2020, 2018b). This will bridge the gap between current market practice and a wider reorientation of capital flows toward sustainable investment by providing a harmonized list of economic activities that can be considered "environmentally sustainable". Global regulatory initiatives for sustainable finance will be in the spotlight this year, driven by the European Commission's efforts to create and regulate a green finance taxonomy. Taxonomies help to create clarity on what is considered green or sustainable and which activities can be labeled as such. In doing so, taxonomies can help to simplify transaction costs to enter the market. However, taxonomies are also generally slow to evolve and prohibitive to inclusion of new technologies.

In the short term, the European Commission's taxonomy may increase costs for issuers. In the long term, the taxonomy could create a robust market for green finance, including a pricing benefit that will occur from a clear and common understanding of what is green. Whether the taxonomy facilitates the growth of the green finance market will depend on if thresholds in the taxonomy are applied as guidance or requirements. From human capital to artificial intelligence and big data, having the expertise and ability to analyze and evaluate ESG impacts, including climate risk 
and opportunity, will become a competitive advantage for banks and asset managers.

\section{Green Finance and SDGs: The Case of China}

According to a report by the Asian Development Bank (2017a), developing Asia will need to invest USD 1.7trillion per year in infrastructure until 2030 to maintain its growth momentum, tackle poverty, and respond to climate change. This estimate covers transport, power, telecommunications, water supply and sanitation, and other urban infrastructure. Investments in these areas must be green if developing Asian countries are to achieve sustainable development in line with the United Nation's SDGs. At a G20 summit held in 2016 in Hangzhou, China, every government head agreed to a shared goal of promoting green finance - a win for China that followed its own plan to pursue a green finance policy (United Nations Climate Change, 2016). China hopes to encourage greater private investment in green sectors to support a low-carbon transformation for its economy, with policy incentives such as a green development fund. China is rapidly emerging as an important testing ground for the development and implementation of green finance policies.

The country has been particularly active recently on the green finance agenda (China Dialogue, 2017). In 2016, the government launched the G20 Green Finance Study Group (GFSG) at the G20 meeting in Hangzhou, which resulted in a seven point plan to scale up green financing globally that was included in the leaders' communique. At the G20 Summit in 2017, the Hamburg Action Plan to address pressing global challenges included GFSG proposals on encouraging financial institutions to undertake environmental risk analysis and improving the availability of environmental data.

\subsection{Challenges to Green Finance in China}

\section{Bottom of Form}

According to Mr. Ma Jun (China Dialogue, 2017), who is chair of the Green Finance Committee in China, special advisor to the UN Environment Programme on Sustainable Finance, and co-chair of the G20 Green Finance Study Group, there are four main challenges faced by green finance in China - a lack of policy signals; loan periods that aren't suitable for long term projects; a lack of capacity building; and a lack of a common definition of 'green assets'.

\subsubsection{A Lack of Policy Signals}

Before the G20 Green Finance Study Group was founded there weren't many international policy signals. It's important to set out and propagate the ideals of green finance to governments, to policymakers, to financial institutions, and to market participants. And domestically, the Chinese government announced Five Provincial-level Trials in June 2016 aimed at reform and innovation in green finance. These will allow each province to pursue their own approach to developing green finance (Shanghai Securities News, 2017). In June 2016, the Chinese government started trials of green finance reform and innovation in Zhejiang, Jiangxi, Guangdong, Guizhou and Xinjiang. There were seen some positive signs, with preferential and stimulus measures taking shape, and some local governments are encouraging local firms to issue green bonds. Each of the five trial areas has its own policy on providing subsidies or underwriting.

\subsubsection{Too Short Terms of Loan Periods from Banks}

Another thing is that if people look into China's banking system, people find the average length of a loan is only two years. So, if people need funding for a ten-year project, they need to raise funds five times. That greatly increases investment risks because if people fail to get the next loan the project is forced to shut down. A lot of green finance projects i.e., subways, railways, water treatment, solid waste, new energy, etc., have lengthy investment periods. It might be 10,15 or even 20 years before investments see a return. This is far beyond the loan periods offered by banks in developing nations.

\subsubsection{A Lack of Capacity of Financial Institutions}

Another challenge is a lack of capacity building. China needs to spend at least five to ten years building capacity in government, financial institutions and academia, and for industry to raise finance. There is a particular need to boost the ability of financial institutions to evaluate environmental risks i.e. to analyze and quantify risks. This is why in its second year the G20 Green Finance Study Group is encouraging financial institutions to analyze environmental risks (Shanghai Securities News, 2017). Green finance designed to encourage more private capital into green sectors and stem investment that might pollute the environment is considered to be one of the key approaches to this end. China now is one of the world's largest issuers of green bonds, which can ease financing demands for medium-and-longterm green projects as banks are limited in offering such services (Shanghai Securities News, 2017).

\subsubsection{A Lack of Taxonomy of Green Finance}

Many green assets haven't been standardized or categorized. So, even if investors want to invest in green assets, they can't find them. Standards for green assets is a hugely complex issue but China is moving more quickly on this than some other countries. China is only halfway 
along this road, but some countries don't have any of these standards. There are many steps to be taken before China gets to a final unified global system of standards for green assets (Shanghai Securities News, 2017).

Many European banks, including the European Investment Bank, have their own market-based rules on green bonds. The earliest cooperation between China and Europe started with the Green Finance Commission and the European Investment Bank, and that is now advanced to the European Commission where there is discussion on whether Europe should have its own standard for green bonds. For developing nations such as China, it is not just about reducing carbon emissions - China also wants to deal with a range of environment issues, such as air, water and soil pollution. Some of those issues aren't significant problems in Europe. So, when defining green bonds, Europe and China have different priorities (Shanghai Securities News, 2017).

\subsection{Recommendations for the Development of Green Finance in China}

Meeting the climate goals set forth in the Paris Agreement will require trillions of dollars of capital over several decades. China's green finance polices are intended, in part, to help meet that need (China Daily News, 2018). Those policies are relatively new and will continue to evolve in the years ahead, in particular, in the followings.

\subsubsection{Enhancing Transparency and Disclosure}

Disclosure of environmental performance information remains insufficient. Within the financial sector, environmental risk analysis capabilities need to be developed. At the same time, due to the lack of tools for environmental risk identification and quantification, some financial institutions underestimate the risks that polluting industry investments may bring. Moreover, most practitioners lack professional knowledge of green industries. According to the China Daily News (2018), China is leveraging financial tools to help green its society and economy. China may introduce an ESG reporting mechanism for listed firms to require more transparency in disclosing information related with environment, social and governance issues.

The securities market watchdog also mulls developing new commodity futures such as carbon emission permit futures to aid air pollution control and counter climate change. The authority focuses more on environmental issues when reviewing IPOs or mergers, while more support is offered to enterprises in green businesses to help them enter and grow in the capital market (China Daily News, 2018). The Shanghai Stock Exchange rolled out a three-year plan in April 2018 with detailed measures to develop green finance such as expanding green bonds, green investment, and international cooperation. In addition, pilots for green corporate bonds have been expanded as part of efforts to promote green finance. Environmental information disclosure by listed companies needs to be rolled out by the Government. This includes improving information statistics and data disclosure across all asset classes and financial services as well as providing data support for green financial policy evaluation, business evaluation of relevant institutions, and future policy revision.

\subsubsection{Building Large Capacity of Financial Institutions for Green Finance}

Two years on from the launch of China's green finance roadmap, the policy momentum is clear. But a range of practical challenges remain. Finance is still not flowing in sufficient volume because environmental externalities are not yet fully internalized in market prices. Externalities can be positive, such that they bring environmental improvements to green projects, or negative, causing environmental damage from polluting projects. At present, due to imperfect Chinese laws and regulations, green benefits cannot be included in investment income and environmental damage is not fully reflected in investment costs (China Daily News, 2018). All of this means awareness of green finance - or indeed, broader ESG factors - has yet to become mainstream. Most financial institutions are still waiting for China's financial regulatory authorities to introduce additional preferential measures for green investment (China Daily News, 2018).

The Chinese government strongly promotes green finance, which the People's Bank of China (PBoC) defines as "financial services provided for economic activities that are supportive of environmental improvement, climate change mitigation and more efficient resource utilization. In September 2016, PBoC promulgated Guidelines for Establishing the Green Financial System -the first time any nation's central bank had issued such guidelines (The People's Bank of China, 2016). PBoC's Green Bond Endorsed Project Catalogue includes "clean utilization of coal" as an eligible project category.

During the first half of 2019, Chinese financial institutions provided more than USD 1 billion to coal projects that qualified as green financing under Chinese standards (China Daily News, 2018). International standards for green bond investments do not include coal projects among the eligible categories. The banks hope that loans for green buildings, low emission vehicles or other environmentally friendly projects could prove interesting to global investors looking to invest in green assets. Perhaps the greatest amount of green finance activity in China has been in the area of green bonds. In 2018, Chinese green bond issuances were roughly RMB283 billion (approximately USD43 billion). This was an increase of roughly $12 \%$ over 2017 and the second highest 
total of any country, behind only the United States (The Climate Bonds Initiative, 2019). Many Chinese provincial and local governments have issued green finance guidance documents. At least five pilot green finance zones have been set up, where financial institutions receive a variety of incentives to fund clean and low-carbon industries. In 2018, Chinese local government entities issued at least USD5.9 billion of green bonds (The Climate Bonds Initiative, 2019).

\subsubsection{Diversifying Green Finance Sources}

As each individual green loan in China is too small for international investors to take notice, selling Chinese green loans requires a process whereby investment banks package a large number of loans together into a single product, which can be traded on China's Bond Connect (The Climate Bonds Initiative, 2019). The Bond Connect is a new mutual market access arrangement that allows investors from Chinese mainland and overseas to trade in each other's bond markets.

The Chinese mainland's first green bond was issued by the Agricultural Bank of China and listed on the London Stock Exchange in October 2015. China has the world's largest green bond market. It accounted for nearly 40 percent of new green bonds in 2016, followed by the United States, France, and Germany (Rooney, 2019). The central government has been pushing for the development of green finance in order to seek sustainable growth and honor its commitments on addressing climate change. The country's banking and securities sectors have issued guidelines that define a green project and outline the eligibility criteria for green bonds issuers (The Climate Bonds Initiative, 2019).

PBoC's Guidelines call for vigorously developing green credit with tools such as central bank relending, guarantee mechanisms and securitization (The People's Bank of China, 2019). China Development Bank's website states that the China Development Bank is one of the earliest advocates of green credit practice in China, which aims to support environmental protection and energy conservation through its designated loans and investments.

\subsubsection{Harmonizing the Standards, Taxonomy, and Measurement of Green Finance}

The lack of consensus on a definition of green is also holding back progress. At present, China has two sets of green bond standards and two sets of green credit standards. In addition, various departments have standards for green agriculture, green buildings, and green manufacturing and technology, but there is no coordination between them (The People's Bank of China, 2019). Ever since the Belt \& Road Initiative was proposed, promoting green finance has always been one of its fundamental missions. Yet, in doing so, one quickly discovered that the Belt \& Road Initiative countries are confronted by some critical issues, such as imperfect environmental data, inadequate financial laws and regulations, lack of system design, and strategy (Belt \& Road News, 2019). Indeed, faced with imperfect top-level design, insufficient innovation of financial products, and inadequate risk management and control, these shortcomings have contributed quite significantly to the slowing down of the Belt \& Road Initiative green finance development.

China's policies with respect to the use of green bond proceeds for coal-fired power plants have created controversy. Those policies allow green bond proceeds to be used for coal-fired power plants in some circumstances, such as when larger, more efficient coal-fired power plants replace smaller, less efficient ones. Some see this as consistent with climate mitigation goals, since carbon emissions are reduced in the short term. Others see this as inconsistent with climate mitigation goals, since larger coal-fired power plants tend to lock in carbon emissions for the medium and long term, and cheaper, less-polluting alternatives may be available. Work is underway to harmonize Chinese and international green bonds standards. Leading international standards prohibit the use of green bond proceeds for coal-fired power plants in all circumstances (EIB \& GFC, 2017). With the above consideration in mind, simply by investing in clean energy or developing green finance is not only insufficient to resolve the issues of economics and livelihood of the Belt \& Road Initiative countries, but it also is not adequate to mitigate the environmental coordination and global climate change (Belt \& Road News, 2019)..

\section{Discussion and Recommendations}

\subsection{For the Private Sector}

According to a report by the ADB (2017b), a large financing need challenges climate-adjusted infrastructure in developing Asia, which is estimated at USD26 trillion till 2030. This necessitates crowding-in private sources to meet financing, efficiency, and technology gaps. However, a lack of bankable projects is a major hurdle. Therefore, the whole financial system needs to be reoriented to support a green economy. To scale up and crowd in private sector finance, governments can team up with a range of actors to increase capital flows and develop innovative financial approaches across different asset classes. Domestic organizations, including national development banks, government agencies, and nationally sponsored climate funds, are playing an increasingly critical role both as providers and as intermediaries of green finance in their countries. This is particularly the case in emerging markets like China and India. The report also highlights the need for a pipeline of bankable green projects, which can be developed through national development planning 
or through financing facilities that support pipeline preparation. Without such pipelines, financing from institutional investors, commercial banks, and capital markets will go elsewhere. Making sure more private sector money, including institutional investor funding, gets channeled towards green infrastructure will play a key role for the future wellbeing of the planet and its inhabitants. The challenge is to incentivize private investors to channel more money into investments that support renewable energy and green infrastructure.

According to a report by the International Finance Corporation (2018), more than USD160 billion in private investment was mobilized by Multilateral Development Banks (MDBs) and Development Finance Institutions (DFIs) in 2017. Further scaling up their capacity to act as intermediaries can have a positive effect on blending and mobilization - their position allows them to bring together a large variety of stakeholders. Bringing together private investors of all types, governments, regulators and other stakeholders helps the learning process that can lead to better policies and thus outcomes on the ground.

\subsubsection{Greening the Banking System}

Promoting green banking involves working with banks to incorporate environmental factors into their lending portfolios. In practice, this means incorporating environmental outcomes in risk and pricing assessments. This potentially increases the cost of debt financing for highpolluting firms, while easing access to lower-cost funding for environmentally conscious firms. Both can help to entrench best green practices throughout the business and financing sectors. In this effort, key initiatives such as the Equator Principles and the UNEP Finance Initiative could be useful. The latter has worked with the banking sector to establish systematic frameworks to manage environmental, social, and governance risks. The end goal is to supply credit and raise capital for green investments, building on the key role of banks in funding for renewable energy and other environmentally sound projects.

In developing Asia, special attention must be given to small- and medium-sized enterprises, since they play an integral economic role in the region and access to green finance is especially difficult for them (ADB, 2017b). According to a report by Stein et al. (2013), over $90 \%$ of informal businesses are proprietorships or partnerships, and many are run by women who face additional challenges linked to gender discrimination, especially in rural areas. This market is largely untapped and offers a revenue generation opportunity for banks and financial institutions willing to introduce innovative financial products.

\subsubsection{Greening the Bond Market}

Green bonds are debt instruments used to finance projects that deliver environmental benefits. The green bond market can offer several benefits, both for green projects and investors, including providing an additional source of green financing to bank lending and equity financing and providing a new class of green assets for investors. Expanding these markets could involve developing local green bond markets, with outside support focusing on data collection, knowledge sharing, and capacity building. Alternately, it could involve promoting international collaboration to facilitate crossborder investment in green bond markets. Although the number of Asian investors driven by environmental and social considerations is not as large as in Europe or the United States, there is a growing pool of interested parties in the region. According to a report by the UN Environment Inquiry (2019), China is the largest driver of the green bond market in Asia with a share of more than $75 \%$. It accounts for $30 \%$ of the world's green bond market.

\subsubsection{Greening Institutional Investors}

Sustainable investing is an investment approach that considers the ESG factors in portfolio selection and management. According to a report by the Global Sustainable Investment Alliance (2016), global investments that incorporate these criteria into their decision-making are growing, reaching USD22.9 trillion in 2016. The global sustainable investment market encompasses a number of activities and strategies. According to the Global Sustainable Investment Alliance (2018), the proportion of sustainable investing relative to total managed assets was still less than $1 \%$ in Asia in 2016, compared with just over 26\% globally. However, the landscape is beginning to evolve, driven by an increasing awareness of the massive capital needed to finance the region's transition to an environmentally sustainable future. The largest Asian markets for sustainable investments by asset size are Malaysia, China, and the Republic of Korea, while fast-growing markets include Indonesia and Singapore.

\subsection{For the Public Sector}

Although the majority of green finance comes from the private sector, public green finance continues to play an important role. Governments can support innovation on the supply side by increasing their direct budget allocations, which can provide flexibility for funding priority green programs and mainstreaming green innovation with current development programs. They can also support procurement and demonstration programs and increase direct research 
and development efforts. The latter can be conducted by governmental agencies or research bodies and backed by subsidized loans and grants. Green business incubators and other similar venture support programs via government or multilateral agency interventions can also play a vital role in helping smaller firms scale up. Together, these measures can help green technologies make the leap from applied research to demonstration.

Meanwhile, bilateral development finance institutions and dedicated environmental finance funds account for the largest share of public finance flowing from developed to developing countries for green finance purposes. They typically provide finance from one developed country to multiple developing countries. Multilateral development banks like the ADB provide funds using their own capital or on behalf of multiple government donors, and through their dedicated funds. ADB also works with and through international environmental finance mechanisms and funds, such as the Global Environment Facility and the Green Climate Fund.

\subsubsection{Developing Policies and Capacity}

As is the case with all policies, administrative simplicity in developing countries is a must. In addition, there must be significant efforts to educate the public. For example, green bonds benefit from using well-known and proven mechanisms, but investors may need help in understanding the definition of green projects. In these efforts, governments can look for opportunities to build capacity. There are growing knowledge-based capacity building platforms, such as the Sustainable Banking Network, the UN-backed Principles for Responsible Investment, and the Green Bond Principles, and efforts among multilateral development banks to harmonize impact-reporting metrics. These initiatives could be expanded to cover more countries and financial institutions to bring in financing for green growth.

Measures can also be taken at a regional level. For instance, the EU Green Bond Standard and the ASEAN Green Bond Standards, which can be tailored at the country level. Based on the Green Bond Standards, these voluntary regional standards help develop a green asset class to support sustainable growth in their countries.

\subsubsection{Promoting Market Transparency and Governance}

One important pre-condition to boost green finance is to improve disclosure. Good disclosure allows financial investors to understand risk properly and to price for that risk. Improving disclosure programs, perhaps by making them mandatory, is essential if decisions are going to be taken on a properly informed basis. For green bonds, for instance, this would involve ensuring that the proceeds are allocated to eligible green investments, with the extra disclosure allowing potential investors to differentiate between green bonds and normal bonds.

Right now, disclosure programs are largely voluntary. For instance, banking group HSBC is disclosing not only its emissions but also the emissions of clients under the Taskforce on Climate-Related Disclosure of the Financial Stability Board. The Sustainability Accounting Standards Board Industry Standards is one example of an independent organization dedicated to facilitating high-quality disclosures. It develops and manages sustainability accounting standards for 79 industries in 11 sectors. Companies are also issuing sustainability reports to disclose corporate environmental, social, and governance performance to its stakeholders. The Global Reporting Initiative has developed guidelines for organizations to assess and report their sustainability performance.

\subsubsection{Promoting Private-Public Partnership for Diversifying Resources}

The International Renewable Energy Agency (2019) estimates that to put the world on track with the objectives of the Paris Agreement, cumulative investment in renewable energy needs to reach USD27 trillion in the 2016-2050 period. This is more than double the amount of the current investment, and presents a great opportunity for investors and developing countries alike. To meet this growing need, new approaches looking at increasing private sector funding for SDGs have been gaining popularity. This is for a good reason. There is a lot of private and institutional capital in the world ready to be deployed in search for better returns. According to McKinsey (2018), private asset managers raised nearly USD750 billion globally in 2018, while institutional investors in OECD countries alone manage around USD100 trillion (World Bank, 2015). At the same time, the investment landscape in developed markets has been changing. Financial conditions in developed economies have been tightening and interest rates are at record lows. According to the MarketWatch (2019), the total amount of negative-yielding bonds is at nearly USD9.7 trillion, an increase of more than $50 \%$ since September 2018. Approximately $27 \%$ of global government debt yields less than $0 \%$, providing some of the lowest returns in years. Contrary to what investors have been used to thus far, the rise of populism in OECD countries coupled with ongoing trade wars has created far greater volatility and uncertainty. Meanwhile, investors' risk perceptions have been slow at catching up with the new realities, with most institutional investors still believing that they can navigate very well any upcoming volatility (Institutional Investor, 2019). 
Now more than ever there are very good financial reasons to diversify portfolios by investing in renewable infrastructure in developing countries. It is also a great opportunity to kill more than two birds with one stone - to improve diversification and returns, spur economic growth in developing countries, and contribute to meeting both the Paris Agreement goals and the SDGs. Stepping up investment in the developing world also makes long-term financial sense - developing countries will be where most of future growth will take place.

\section{Conclusion}

It is high time to leverage the rising pressures on companies and investors to become more sustainable. As climate change effects become more visible and public outrage grows, pressures for more sustainable practices will grow simultaneously. This means that there will be greater opportunities to improve SDG financing as investors seek positive impact. The main challenges will remain the same as they were a few years ago, for example, how to ensure that increasing private investment is aligned with the developing country needs and has the optimal development impact on the ground. These challenges, however, have always applied both to public and private investments. Continuous work on improving country ownership and transparency can help. So, can efforts to better align stakeholder expectations and practices. An enabling framework that promotes green finance can address these problems and help change people's mindsets and behaviors. On the fiscal and taxation side, subsidies for fossil fuels could be phased out, while subsidies for green products could be phased in. On the legal side, information disclosure could be made mandatory, along with environmental insurance. Banks could also be made accountable for the environmental damage of the companies they lend to, a concept referred to as lender's liability.

All things considered, there is still one important truth to bear in mind. Scalability and standardization come with trade-offs. According to Volz (2018), impact investing and SDG-aligned investing has seen unprecedented growth in the last few years, but measuring the actual impact of this growth has lagged. Of course, different approaches may well be needed for different countries. A one size-fits-all is unlikely to work everywhere, but with new technologies and improved data, it should be possible to tackle some of the issues better than before, and to improve transparency something that has been on the agenda for a long time.

Transparency will also allow keeping an eye on whether environmental and social responsibilities are met, which will be important when trying to scale up the investments. In the past, part of the problem has been the different actors existing in separate universes, with not enough opportunities to interact and discuss face-to-face. The growing salience of climate emergency and SDGs has led to some positive changes, helping to create a wider debate between all stakeholders. This needs to be kept up and built upon, so that the different professional communities do not stay in their silos. In conclusion, the world has now enough expertise and money to address the SDG challenges, now it is all about fitting the pieces of the puzzle together. So, while there is still a long way to go, hopefully the going keeps getting better.

\section{References}

Asian Development Bank. (2017a, February). Meeting Asia's Infrastructure Needs. Manila, Philippines. Retrieved from https://www.adb.org/publications/asia-infrastructure-needs

Asian Development Bank. (2017b, August). Catalyzing Green Finance: A Concept for Leveraging Blended Finance for Green Development. Retrieved from https://www.adb.org/ publications/green-finance-catalyzing-facility

Belt \& Road News. (2019, August). Challenges of Developing Green Finance in the Belt \& Road Initiative. Retrieved from: https://www.beltandroad.news/author/bd/

China Daily News. (2018, May). China Eyes Clean Development via Green Finance. Retrieved from: http://www.chinadaily. com.cn/a/201805/22/WS5b03dff2a3103f6866ee9e40.html

China Dialogue. (2017, October). Ma Jun: China's Green Finance Needs to Take into Account Climate Change and Environmental Pollution. Retrieved from: https://www.chinadialogue.net/ authors/2942-Xue-Han

Climate Disclosure Standards Board (CDSB). (2018, March). Ready or Not: Are Companies Prepared for the TCFD Recommendations?. Joint CDSB and CDP Report. Retrieved from: https://www.cdsb.net/sites/default/files/tcfd preparedness_report_final.pdf

European Commission. (2018a, December). Vice-President Valdis Dombrovskis: College Read-Out and Remarks on the Italian Budget. Retrieved from: https://europa.eu/rapid/press-release_ SPEECH-18-6886_en.htm

European Commission. (2018b, January). Sustainable Finance: High-Level Expert Group Delivers Roadmap for Greener and Cleaner Economy. Retrieved from: https://europa.eu/rapid/ press-release_IP-18-542_en.htm?locale=en

European Commission. (2002, March). Taxonomy: Final Report of the Technical Expert Group on Sustainable Finance. The EU Commission's Technical Expert Group. Retrieved from: https:// ec.europa.eu/info/sites/info/files/business_economy_euro/ banking_and_finance/documents/200309-sustainable-financeteg-final-report-taxonomy_en.pdf

EIB \& GFC: European Investment Bank and the Green Finance Committee of China Society for Finance and Banking. (2017, November). The Need for a Common Language in Green Finance. Working Paper. Retrieved from: https://www.eib. 
org/attachments/press/white-paper-green-finance-commonlanguage-eib-and-green-finance-committee.pdf

Financial Times. (2018, December). Brussels Looks at Easing Bank Capital Rules to Spur Green Investment. Retrieved from: https://www.ft.com/content/40df2780-e708-11e7-97e2$916 \mathrm{~d} 4 \mathrm{fbac} 0 \mathrm{da}$

Global Sustainable Investment Alliance. (2016). The Global Sustainable Investment Review 2016. Available at: http:// www.gsi-alliance.org/wp-content/uploads/2017/03/GSIR_ Review2016.F.pdf

Global Sustainable Investment Alliance. (2018). The Global Sustainable Investment Review 2018. Available at: http:// www.gsi-alliance.org/wp-content/uploads/2019/06/GSIR_ Review2018F.pdf

Institutional Investor. (2019). Institutional Investors Think They're Ready for the Next Downturn. Retrieved from: https:// www.institutionalinvestor.com/article/b1 fhbsnhk41 bmc/ Institutional-Investors-Think-They-re-Ready-for-the-NextDownturn

International Finance Corporation. (2018, June). Mobilization of Private Finance by Multilateral Development Banks and Development Finance Institutions 2017. Retrieved from: https://www.ifc.org/wps/wcm/connect/publications ext content/ifc_external_publication_site/publications_listing _ page/2018_mdb-mobilization-report

International Renewable Energy Agency. (2019, April). Global Energy Transformation: A Roadmap to 2050. Retrieved from: https://www.irena.org/publications/2019/Apr/Global-energytransformation-A-roadmap-to-2050-2019Edition

MarketWatch. (2019). Amount of Global Debt Yielding Less Than 0\% Approaching \$10 Trillion. Retrieved from: https://www. marketwatch.com/story/amount-of-global-debt-yielding-lessthan-0-approaching-10-trillion-2019-03-22

McKinsey \& Company. (2018). The Rise and Rise of Private Markets: McKinsey Global Private Markets Review 2018. McKinsey \& Company.

Rooney, K. (2019, September 12). These Countries Are Leading the Way in Green Finance. The World Economic Forum. Retrieved from: https:/www.weforum.org/agenda/2019/09/ these-countries-are-leading-the-way-in-green-finance/

Shanghai Securities News. (2017, June). The Central Bank Disclosed Details of the Five Provinces (Districts) Green Financial Reform Pilot. Retrieved from: http://news.cnstock. com/news,bwkx-201706-4090751.htm
Stein, P., Ardic, O. P., \& Hommes, M. (2013). Closing the Credit Gap for Formal and Informal Micro, Small, and Medium Enterprises. Working Paper, International Finance Corporation, Washington, DC. Available at: https://openknowledge. worldbank.org/handle/10986/21728.

Sustainalytics. (2019, March). Trends in Sustainable Finance for 2019. Retrieved from: https://www.sustainalytics.com/ sustainable-finance/2019/03/06/trends-in-sustainable-financefor-2019/

The Climate Bonds Initiative. (2019, February). China Green Bond Market 2018. Retrieved from: https://www.climatebonds.net/ resources/reports/china-green-bond-market-2018

The People's Bank of China. (2016, September). Guidelines for Establishing the Green Financial System. Retrieved from: http://www.pbc.gov.cn/english/130721/3133045/index.html

The People's Bank of China. (2019, January). 2018 Financial Statistics Report. Retrieved from: http:/www.gov.cn/ xinwen/2019-01/15/content_5358086.htm

UN Environment Inquiry. (2019, March). Sustainable Finance Progress Report. UN Environment Inquiry. Available at: http:// unepinquiry.org/wp-content/uploads/2019/03/Sustainable_ Finance_Progress_Report_2018.pdf

United Nations Climate Change. (2016, September 6). G20 Leaders Commit to Boost Global Growth. The UNFCCC Secretariat. Retrieved from: https://unfccc.int/news/g20-leaders-committo-boost-global-growth

United Nations Environment Programme. (2018, November). UN Environment Finance Initiative and 28 Banks Launch Public Consultation on Principles for Responsible Banking. Retrieved from: https://www.unenvironment.org/news-and-stories/ press-release/un-environment-and-28-banks-launch-publicconsultation-principles

United Nations Environment Programme. (2020). Green Financing. Retrieved from: https:/www.unenvironment.org/es/ node $/ 20885$

Volz, U. (2018). Fostering Green Finance for Sustainable Development in Asia. ADBI Working Paper No. 814. Tokyo: Asian Development Bank Institute. Available at: https://www. adb.org/sites/default/files/publication/403926/adbi-wp814.pdf

World Bank. (2015). Institutional Investors: From Myth to Reality. Retrieved from: http://pubdocs.worldbank. org/en/319711481736949205/Sergio-Schmukler-PRTInstitutional-Investors-1June2015.pdf 